TARNOWSKIE STUDIA TEOLOGICZNE 34 (2015) NR 2, S. 151-153

http://dx.doi.org/10.15633/tst.1645

dk. Michał Sapalski

UNIWERSYTET PAPIESKI JANA PAWŁA II W KRAKOWIE

\title{
„Moim honorem jest honor Kościoła” Konferencja o arcybiskupie Jerzym Ablewiczu
}

15 kwietnia 2015 roku w auli Wyższego Seminarium Duchownego w Tarnowie im. św. Jana Pawła II, 25 lat po śmierci abp. Jerzego Ablewicza, miało miejsce sympozjum poświęcone temu wybitnemu pasterzowi diecezji tarnowskiej.

Spotkanie otwarło słowo wstępne dziekana wTST UPJPII ks. dr. hab. Janusza Królikowskiego, prof. UPJPII. Przypomniał on o ścisłej więzi i łączności między biskupem a wiernymi w pierwotnym Kościele. Wówczas wyrażało się to najwyraźniej w liturgii, która zawsze najpełniej odzwierciedla wiarę i świadomość Kościoła - ówcześnie cząstkę Najświętszego Sakramentu konsekrowanego przez biskupa diakoni dostarczali do kościołów parafialnych, w których prezbiterzy dokładali tę cząstkę Sanctissimum do hostii przezeń konsekrowanych. Był to wyraźny znak jedności wspólnoty z biskupem. Kościół bowiem zawsze rodził się wokół biskupa i z biskupem. Stąd starożytni chrześcijanie mawiali: „Ubi episcopus, ibi Ecclesia - Gdzie biskup, tam Kościół”. 28 lat posługi abp. Jerzego Ablewicza, jednego z następców apostołów, wpisującego się w krąg filarów Kościoła, jest okazją do głębszej refleksji nad jego osobą i działalnością pasterską. Każdy biskup buduje bowiem Kościół partykularny wedle indywidualnych rysów, ubogacając tym samym Kościół powszechny, i sympozjum miało na celu choć po trosze scharakteryzować cechy pasterskie abp. Ablewicza.

Następnie głos zabrał trzeci następca abp. Ablewicza na katedrze tarnowskiej, bp Andrzej Jeż. Zaznaczył on, że styl posługi abp. Ablewicza miał wielki formacyjny wpływ na kapłanów diecezji tarnowskiej, co wyraźnie odbijało się w ich duszpasterskiej posłudze. Biskup Kościoła w Tarnowie przywołał też wspomnienie kard. Grocholewskiego, który przypomniał, że abp Jerzy Ablewicz podczas każdej wizyty w Rzymie odwiedzał wszystkie Kongregacje, chcąc skonsultować się z najbliższymi współpracownikami Ojca Świętego, w jaki sposób przenosić wzorce z Kościoła powszechnego 
do Kościoła lokalnego. Widać przez to wyraźnie, jak abp Ablewicz pragnął wiernie i wytrwale budować Kościół apostolski. De facto temat Kościoła apostolskiego stał się wiodącym zagadnieniem jednej z konferencji wygłoszonej podczas papieskich rekolekcji w 1981 roku, które arcybiskup prowadził.

Biskup gliwicki dr hab. Jan Kupiec w obszernym wystąpieniu podjął analizę relacji między biskupem a Stolicą Apostolską. Wskazał, że Kościół w Rzymie w średniowiecznym ujęciu to caput, cardo et fundamentum, tj. głowa, zawias i fundament całego Kościoła. Rozumienie to pogłębiły na przełomie pierwszych dwóch tysiącleci reformy gregoriańskie. Bp Kupiec zaznaczył m.in., iż tworzenie nowych biskupstw nigdy nie było tylko i wyłącznie aktem administracyjnym, ale działaniem konstytutywnym dla życia Kościoła, w myśl przytaczanej wyżej sentencji „Gdzie biskup, tam Kościół”. Zauważył też, że prawo nominacji nowych biskupów, istotne zadanie Kościoła, z czasem zostało scedowane na biskupa Rzymu, podobnie jak przywilej ustanawiania nowych diecezji. Obowiązek ad limina apostolorum, tj. pielgrzymki do grobów apostolskich i wizyta u Ojca Świętego, był i pozostał kolejnym wyrazem ścisłej łączności biskupa Rzymu z innymi biskupami. Abp Jerzy Ablewicz wiernie spełniał tenże obowiązek, który jednocześnie był dla niego wielkim przywilejem.

Następnie ks. prof. dr hab. Tomasz Rozkrut, dziekan Wydziału Prawa Kanonicznego UPJPII w Krakowie, w interesujący sposób pozwolił nam przyglądnąć się charakterystycznym cechom Jerzego Karola Ablewicza, biskupa tarnowskiego w latach 1962-1990. Abp Ablewicz znał bardzo dobrze abp. Karola Wojtyłę, był bowiem sufraganem w archidiecezji krakowskiej, gdy przyszły papież piastował urząd metropolity krakowskiego. Stąd też zrodziła się między nimi zażyła i serdeczna znajomość. Abp Ablewicz był nadto jednym z ojców Soboru Watykańskiego II, a jednocześnie realizatorem soborowych postulatów. Vaticanum II był dla niego znakiem czasu, stąd nawoływał do gorącej modlitwy o jego owocną percepcję w Kościele. Tak silne zetknięcie się z Kościołem powszechnym, reprezentowanym przez biskupów ze wszystkich kontynentów i różnych denominacji chrześcijańskich stało się też dla abp. Ablewicza impulsem do działalności misyjnej. Ona jest kolejnym specyficznym rysem jego posługiwania - to właśnie za jego czasów pierwsi kapłani diecezji tarnowskiej wyjechali na misje. 6 marca 1981 roku abp Ablewicz został członkiem Kongregacji ds. Świętych i Błogosławionych i w marcu tegoż roku wygłosił rekolekcje wielkopostne dla Ojca Świętego Jana Pawła II oraz jego najbliższych współpracowników. Arcybiskup w swej 
posłudze biskupiej często wołał za Grzegorzem Wielkim: „Moim honorem jest honor Kościoła”. Mając na uwadze dobro Kościoła w Tarnowie, zwołał w 1986 roku IV Synod Diecezji Tarnowskiej. 10 kwietnia 1987 roku, w dniu beatyfikacji Sługi Bożej Karoliny Kózkówny i po 25 latach od rozpoczęcia służby pasterskiej w diecezji, ówczesny biskup tarnowski Jerzy Ablewicz otrzymał z rąk Jana Pawła II tytuł arcybiskupa honorowego. Skromny, zatroskany o dobro Kościoła, Ojczyzny i zbawienie każdego człowieka - tak najogólniej rzecz ujmując, scharakteryzował osobę abp. Jerzego Ablewicza ks. prof. Tomasz Rozkrut.

Ks. dr Andrzej Dudek zaprezentował imponujący wykaz dzieł abp. Ablewicza i powstałych dotąd trzech bibliografii obejmujących jego dorobek. Dowiedzieliśmy się też, że osobie arcybiskupa poświęcono ok. 50 poważnych artykułów naukowych i kilkanaście prac magisterskich. Po nim ks. Jacek Słowik, zastępca dyrektora Archiwum Diecezjalnego im. abp. J. Ablewicza w Tarnowie, wymienił i pokrótce opisał zbiory muzealne związane z osobą byłego pasterza diecezji, jak np. dyplom doktorski z filozofii, prywatne listy od Jana Pawła II, herb biskupi ze św. Jerzym tratującym smoka, niektóre homilie i odezwy pasterskie, kilka manuskryptów, maszynopis watykańskich rekolekcji i pracy doktorskiej, skrypty, okolicznościowe albumy zdjęć czy luźne fotografie.

Na koniec ksiądz infułat Władysław Kostrzewa złożył osobiste świadectwo o abp. Ablewiczu, podkreślając, że dla abp. Jerzego ogromną radością była możliwość posługi w Kongregacji ds. Świętych i Błogosławionych. Wyraził też nadzieję na rychłe rozpoczęcie jego procesu beatyfikacyjnego. Zwieńczeniem sympozjum było słowo bp. Andrzeja Jeża, inicjatora sesji poświęconej abp. Jerzemu Ablewiczowi, „oddanemu współpracownikowi rzymskiej Kongregacji”, jak określił zmarłego 8 maja 1987 roku w telegramie kondolencyjnym Ojciec Święty Jan Paweł II. 